\title{
KECENDERUNGAN SIFAT FATIK DAN KONSTANTA PERSAMAAN PERAMBATAN RETAK STAINLESS STEEL-304 TERHADAP PERBEDAAN DIMENSI DAN RASIO BEBAN
}

\author{
Tungga Bhimadi $^{1^{*}}$, Rizqiyatul Khoiriyah ${ }^{2}$, Budiono $^{3}$ \\ (1)(2) (3) Universitas Gajayana Malang \\ tunggabhimadi2@gmail.com
}

\begin{abstract}
Abstrak.
Tiga daerah perambatan retak, ditimbuhkan dari beban fatik yaitu: kondisi permulaan mulus sebelum retak sampai retak awal ukuran sesuai regulasi sebagai daerah-1, retak mulai tembus ketebalan kemudian retakan bagian atas dan bawah merambat bersaman sampai daya dukung material sudah tidak memungkinkan sebagai daerah-2, dan rambatan retak cepat sampai struktur patah sebagai daerah-3. Empat model dari pakar persamaan perambatan retak, dipopulerkan yaitu persaman: Paris (linear pada daerah-2), Walker (parabolik, pada daerah-1 dan 2), Forman (hiperbolik pada daerah 2 dan3), dan Collipriest (kurva-S untuk daerah 1-2 dan 3). Uji fatik 14 spesimen plat berlubang Stainless Steel-304 (SS-304) beban fatik amplituda konstan, dilakukan dengan data variasi dari tebal, diameter lubang, dan rasio beban. Hasil sifat fatik diperoleh: untuk tebal $3 \mathrm{~mm}$ konstan dan rasio beban 0.9 konstan, diameter lubang bertambah dari $12 \mathrm{~mm}$ sampai $20.75 \mathrm{~mm}$, maka kecenderungan sifat fatik SS-304 yaitu: Intensitas Tegangan Threshold $\left(K_{t h}\right)$ terus naik, Plane Strain Fracture Toughness (Kic) naik terus, Plane Strees Fracture Toughness $(\mathrm{Kc})$ turun terus, $\mathrm{K}_{\text {maks }}$ atau Maximum Stress Intensity Factor terus turun, koefisien $\mathrm{C}$ persamaan Paris naik tetapi untuk m turun, koefisien persamaan Walker naik kemudian turun, dab tiga koefisien persamaan Collipriest selalu turun..
\end{abstract}

Kata kunci: sifat fatik, skala logaritmik, dan persamaan perambatan retak

\begin{abstract}
.
Three locations of crack propagation are rised by fatigue loads. The initial condition from smooth before cracking until the initial crack is determined according to the regulations, as region-1. The crack stars to penetrate the thickness then the upper and lower cracks propagate together until the material has stress as same as its strength valu, as area-2, and fast crack propagation until the structure failure as a 3-region. Four mathematisc models from experts on crack propagation equations, were popularized, namely the equation: Paris (linear in region-2), Walker (parabolic, in regions-1 and 2), Forman (hyperbolic in regions 2 and 3), and Collipriest (S-curve for regions 1-2 and 3). The fatigue test of 14 specimens of open hole plate Stainless Steel-304 (SS-304), constant amplitude, was carried out by using variation data of thickness, hole diameter, and load ratio.The results of fatigue properties are obtained: for a constant 3mm thickness and a constant 0.9 load ratio, but the hole diameter were increased from $12 \mathrm{~mm}$ to $20.75 \mathrm{~mm}$. The tendency of fatigue properties of SS-304 are: Threshold Stress Intensity (Kth) continued to increase, Plane Strain Fracture Toughness (Kic) increased continue, Plane Strees Fracture Toughness (Kc) continues to fall, Kmaks or Maximum Stress Intensity Factor continues to fall, the coefficient $C$ of the Paris equation increases but for $m$ werw decreases. The coefficient of the Walker equation rises then falls, and the three coefficients of the Collipriest equation always decrease.
\end{abstract}

Keywords: fatigue properties, mathematisc models, and crack propagation

\section{PENDAHULUAN}

Dengan latar belakang, sebuah konsep prosedur penerapan produk dinyatakan dalam dua kelompok yaitu konsep: teknologi dan non teknologi. Penerapan konsep non teknologi dari transparansi prosedur, meski tidak sepenuhnya dilaksanakan sesuai prosedur, produk masih 
berhasil dibuat. Tidak demikian halnya dengan 'konsep non teknologi', prosedur konsep ini tidak dapat dibedakan atau diselewengkan, Bhimadi [1]. Jika produk yang dibuat dari SS-304 dan regulasi mensyaratkan analisa kekuatan terhadap beban fatik, maka uji fatigue dilaksanakan dalam tataran konsep teknologi dengan urutan prosedur yang rawan keberhasilannya bila diselewengkan. Uji fatigue harus dilaksanakan dengan tujuan untuk mendapatkan syarat kelayakan produk sesuai regulasi.

Regulasi diterbitkan oleh otoritas setempat. Regilasi untuk produk konstruksi, dikelompokkan sesuai dengan beban riil yang diterima produk konstruksi tersebut. Beban riil umumnya ditimbulkan dari kejadian operasional produk oleh akumulasi semua jenis beban yang ada. Setiap jenis beban diikuti dengan regulasi. Regulasi produk disesuaikan persyaratan. Sampai saat ini jenis beban disebutkan sesuai perbedaan frekuesi pembebanan pada produk konstruksi, yaitu beban: static, korosi, fatigue, flutter, bration, dynamic, impact, gempa, buckling, dan crippling. Regulasi paling awal dimunculkan untuk jenis beban statik, demikian selanjutnya regulasi untuk: beban getaran, beban fatik, dan beban gempa. Regulasi terakhir yang muncul setelah tahun 1995, diberlakukan untuk beban impak, Bhimadi [2].

Kombinasi gaya dan momen dari setiap jenis beban termasuk beban fatigue pada lokasi struktur yang dianalisa, dapat ditimbulkan oleh beban posisi jauh dari objek struktur. Persamaan Mohr dapat diterapkan untuk konversi beban kombinasi tersebut hanya sebagai beban tariktekan, dengan arah dan orientasi bidang sesuai harga tegangan maksimum. Harga beban tariktekan ini dapat digunakan sebagai beban uji fatigue uniaksial amplitude konstan, Bimadi [3]. Dua kelompok beban fatik, ditinjau dari efek retakan pada material apakah pada material getas atau ulet, yaitu: Fatigue Life Loads untuk material getas karena setelah muncul initial crack maka rambatan cepat dan langsung material rusak, dan Crack Growth Loads untuk material ulet karena rambatan retan terjadi selang waktu lama sebelum material rusak atau retak dapat ditahan. Sifat fatik material getas, diperoleh dari uji bending dengan putaran beban konstan. Putaran ini memberi gaya tarik tekan specimen dari efek bending yang terjadi. Observasi data pengamatan dari uji bending, dinyatakan dengan diagram tegangan ijin (S) fungsi dari jumlah siklus beban $\mathrm{N}$ untuk sejumlah specimen. Satu specimen ditunjukkan dengan harga satu titik dalam diagram S-N. Sifat fatik material ulet, diperoleh dari uji fatigue beban uniaksial amplitude konstan. Observasi data uji fatuge material getas disebutkan dari harga antara lain yaitu: rasio beban, kekuatan static, panjang retak, dan jumlah siklus beban, Juvinal [4]. Hasil untuk beban fatigue pada material ulet, ditampilkan dalam diagram (da/dn) terhadap $(\Delta \mathrm{K})$. (da) disebut sebagai perubahan panjang retak untuk harga $(\mathrm{dn})$ yaitu pertambahan jumlah siklus beban. $(\Delta \mathrm{K})$ disebut sebagai perubahan Faktor Konsentrasi Tegangan. Material Stainless Steel 304 (SS-304) dikelompokkan sebagai material ulet,

Ketahanan material terhadap jenis beban tertentu ditentukan oleh harga sifat material sesuai jenisnya masing masing apakah sudah dipenuhi. Syarat material pada produk tahan terhadap beban fatigue, disebutkan dari harga misalnya faktor intensitas tegangan, kekuatan patah, kekuatan threshold, dan faktor konsentrasi tegangan. Hal ini diperlukan uji material tersebut. Sifat material untuk keperluan desain atau permesinan pada setiap literatur, umumnya dinyatakan dengan satu harga. Setiap jenis spesimen dari material yang sama, meskipun dengan repetisi percobaan, diperoleh harga sifat fatik berbeda. Perbedaan harga sifat fatik ini dipengaruhi oleh variasi rasio beban, dan variasi dimensi dari produk. Isue masalah kecenderungan harga sifat fatigue dan bagaimana pengaruh sifat fatuigue variasi hasil uji fatik, dihubungkan dengan perubahan dimensi specimen uji dan rasio beban. Harga sifat fatik hasil analisa yang bagaimana, digunakan untuk desain atau kebutuhan lain. Uji fatigue solusi harga sifat fatik SS-304 dalam penelitian ini, dilakukan pada 14 spesimen. Prosedur standar harga 
dari uji fatik, diawali dari data harga panjang retak, dan untuk setiap jumlah delta siklus beban. Plot panjang retak sebagai fungsi siklus beban kurva bentuk parabola, diperoleh. Kurva ini ditransformasikan menjadi kurva Kecepatan Perambatan Retak (da/dn) sebagai fungsi dari Delta Faktor Intensitas Tegangan $(\Delta \mathrm{k})$. Harga aspek sifat fatik SS-304 rujukan yaitu dua konstanta $(\mathrm{C}$ dan n) pada persamaan Paris, sudah dilakukan bersama 114 logam ulet lain untuk kebutuhan analisa fatik pesawat ruang angkasa, dari $\mathrm{Hu}[5]$.

Harga konstanta Paris ( $\mathrm{C}$ dan $\mathrm{n}$ ) disebutkan hanya pengaruh jenis material saja. Informasi material ini dalam Shuttle Orbiter Division [6], disebutkan tetapi tanpa kelengkapan sifat fatik lain untuk prosedur dan informasi jumlah banyak spesimen pada uji fatik dan pengaruh variasi dimensi dan rasio beban. Sifat fatik material lain dari Schijve [7] yaitu: harga $\mathrm{K}_{\text {maks }}$ atau Maximum Stress Intensity Factor (Faktor Intensitas Tegangan Maksimum) material patah dan harga Delta Faktor Konsentrasi Tegangan $(\Delta \mathrm{k})$ saat material patah, dinyatakan juga hanya tergantung jenis material. Tegangan $(\Delta \mathrm{k})$ saat material patah, sebagai input data hasil uji fatik regresi daerah-3. Harga $K_{\text {maks }}$ digunakan pada koefisien regresi uji fatik dari persamaan perambatan retak Walker untuk penentuan perioda inspeksi.

Kc, Plane Stress Fracture Toughness atau koefisien regresi data uji fatik, diperoleh untuk diaplikasikan sebagai konstanta persamaan perambatan retak Forman dan Collipriest sebagai harga batas maksimum kondisi retakan plane stress. Kic identik dengan Kc atau Plane Strain Fracture Toughness, diperoleh sebagai harga batas minimum kondisi retakan plane strain. $\Delta$ ko atau Delta Faktor Konsentrasi Tegangan pada kondisi struktur mulus sebagai koordinat mendatar dalam kurva, digunakan pada spesimen dari kondisi rambatan retak dari struktur mulus sampai timbul initial crack sesuai regulasi. Regulasi diberikan untuk SS-304 dengan retak awal 0.0125 inc. $\Delta \mathrm{k}_{\text {th }}$ atau Faktor Intensitas Tegangan Threshold, diperoleh dari regresi kondisi retak mulai merambat dalam daerah-1. Kurva asimtotik $\Delta \mathrm{k}$ kondisi konvergen dari persamaan Collipriest diperoleh. Kondisi retak tidak merambat, diperoleh untuk harga $\Delta \mathrm{K}<\Delta \mathrm{K}_{\mathrm{th}}$. Harga $\Delta \mathrm{K}_{\text {th }}$ digunakan sebagai desain perbaikan, jika retak harus dipaksa tidak merambat, misalnya dengan memasang crack stopper atau stiffener. Hipotesa awal diberlakukan sebelum uji fatik. Semua harga sifat fatik umumnya dan untuk SS-304 khususnya dibedakan sesuai variasi dimensi dan rasio beban.

\section{METODE PENELITIAN}

\section{Tahapan Penelitian}

Tahapan penelitian dirumuskan untuk mendapatkan variasi sifat fatigue SS-204, dan koefisien dan konstanta persamaan perambatan retak SS-304, akibat variasi rasio beban dan dimensi, yaitu:

a. Uji tarik terhadap 6(enam) spesimen SS-304 direncanakan untuk dilakukan. Harga sifat mekanik (yaitu: kekuatan tarik, kekuatan yield, perpanjangan, dan Modulus Elastiditas) diperoleh dari data. Observasi data dilakukan untuk penentuan harga kekuatan yield uji fatigue.

b. Tinjauan jumlah jenis penyimpangan uji fatik terhadap kondisi ideal sesuai desain, dirumuskan sebagai observasi penentuan kelayakan saat pemilihan data untuk amalisa,

c. Mesin uji fatik disiapkan.

d. Observasi ketidakpastian diberlakukan dari operasional mesin uji fatik.

e. Specimen dan form pengamatan disiapkan.

f. Mesin uji fatigue dioperasikan untuk uji fatigue preparatory.

g. Uji fatigue dan pengamatan perambatan retak diberlakukan untuk semua specimen.

h. Observasi data dilakukan untuk membuat kurva perambatan retak.

i. Linearisasi persamaan perambatan retak diaplikasikan. 
j. Observasi kecenderungan sifat fatik divariasikan terhadap dimensi specimen dan rasio beban.

k. Tahap akhir penelitian dirimuskan dari kegiatan Result and Discussion

\section{Uji Tarik}

Harga yield strength SS-304 diperoleh dari uji tarik. Tarikan sebagai tekanan $(\mathrm{P})$ dari mesin tarik, dilakukan untuk mendapatkan hasil pertambahan panjang $(\Delta \mathrm{l})$ specimen. Hasil uji tarik ini, ditampilkan pada kertas berskala sebagai plot kurva $(\mathrm{P})$ sebagai fungsi dari elongation (e) dari harga rasio $(\Delta \mathrm{l})$ terhadap panjang awal (lo) atau $(\mathrm{e}=\Delta \mathrm{l} / \mathrm{lo})$. Harga tekanan tiga kondisi yaitu: yield, ultimate, and fracture, ditampilkan dari operasi mesin tarik. Harga tegangan tiga kondisi ini dapat dihitung dari luas penampang specimen, sesuai hasil plot pada kertas ber-skala, saat operasional uji tarik. Kurva (P) fungsi (e) dikonversikan menjadi kurva tegangan tarik (S) fungsi dari regangan $(\varepsilon)$, atau $\left(\mathrm{S}=\mathrm{P} / \mathrm{Ao}^{*}(1+\mathrm{e})\right)$ dan $(\varepsilon=\ln (1+\mathrm{e}))$. Kurva $\sigma$ - $\varepsilon$ diasumsikan dengan pendekatan fungsi sebagai $\left(\sigma=K \varepsilon^{\mathrm{n}}\right),(\mathrm{K})$ konstanta, Dieter [8].

Parameter hasil uji tarik diperoleh yaitu: perpanjangan yied, perpanjangan ultimate, perpanjangan fracture, perpanjangan offset, perpanjangan plastis, kekuatan yield, kekuatan ultimade, kekuatan fracture, dan modulus elastisitas. Sebagaian sifat mekanik dari uji tarik digunakan untuk parameter uji fatigue, yaitu: kekuatan ultimate (85 ksi dan $87.2 \mathrm{ksi}$ ) untuk memastikan kemampuan mesin uji. kekuatan yield ( $35 \mathrm{ksi}$ dan $36.1 \mathrm{ksi}$ ) untuk referensi penentuan rasio beban fatigue, persen elongation atau $(\varepsilon)$ saat patah (55 dan 50.8 dalam prosentase) untuk memastikan kemampuan alat pencatat panjang retak, dan Modulus Elastisitas (28 ksi dan 24.2 ksi) untuk evaluasi dari harga sifat fatigue dari percobaan. Antara rujukan dan hasil uji tarik ditunjukkan angka dalam kurung. Harga uji tarik ini digunakan untuk uji fatigue. Referensi digunakan sebagai tinjauan memastikan kewajaran hasil.

\section{Jenis Penyimpangan dan Dimensi Spesimen}

Tujuh penyimpangan uji fatigue diobservasi berasal dari sebagai berikut, Bhimadi [9]:

a. Perbedaan riil dimensi spesimen dengan dimensi desain, perambatan retak dipengaruhi harga frekuensi percobaan tetapi harga uji fatige ini ditentukan sesuai kemampuan maksimum mesin dari uji preparatory.

b. Pencatatan panjang retak dan jumlah siklus beban diperoleh dari alat berbeda sehingga ada delay waktu.

c. Penyimpangan konversi arus litsrik menjadi defleksi actuator tidak dapat ideal nol beban karena untuk konsidi awal beban tetap ada harga. Penerapan rasio beban fatigue tidak diperoleh konstan.

d. Clamp kedua ujung specimen sudah diposisikan tengah tetapi efek bending spesimen ditimbulkan akibat panjang rambatan retak dua sisi permukaan tidak sama.

e. Asumsi harga rata rata rambatan retak dua permukaan digunakan untuk analisa sehingga harga ekstrem dua permukaan tidak dapat dihindari.

f. Hasil akhir kondisi retak saat patah diperoleh tidak sama pada empat permukaan.

g. Pemilihan selang waktu pengamatan disertakan dengan harga penyimpangan panjang retak akibat delay time.

Pembuatan dimensi specimen diupayakan sesuai dengan harga desain. Ppembuatan dengan Electric Discard Machine (EDM), diperoleh penyimpangan sesuai dalam tabel-1, Bhimadi [9]. L, T, dan D, singkatan dari masing masing yaitu: lebar, tebal, dan diameter lubang spesimen.

Rasio beban (R) sebagai perbandingan beban aplikasi terhadap beban ultimate, digunakan yaitu: 0.9 untuk spesimen-1 sampai dengan spesimen-4, 0.7 untuk spesimen-5 dan spesimen-6, 0.9 untuk spesimen-7 dan spesimen-9 serta spesimen-11. Specimen sisanya digunakan rasio beban 0.7. Tebal plat SS-304 masing-masing spesimen dibuat dengan: $3 \mathrm{~mm}$ untuk spesimen (1, 2, 3, 6, 11, dan 14), $6 \mathrm{~mm}$ untuk spesimen $(7,10,11$, dan 13), dan $8 \mathrm{~mm}$ untuk spesimen $(4,5,8$, 
9, dan 12). Lebar spesimen divariasikan untuk: $60 \mathrm{~mm}$ pada spesimen (5 dan 14), $50 \mathrm{~mm}$ pada spesimen (1,2, dan 3), $40 \mathrm{~mm}$ pada spesimen-9, $35 \mathrm{~mm}$ pada spesimen $(7,8,11,12,13)$, dan 30 mm pada spesimen ( 4, 6, dan 10). Diameter lubang pada plat untuk 14 spesimen ditentukan yaitu: $20.75 \mathrm{~mm}$ untuk spesimen-3, $15 \mathrm{~mm}$ untuk spesimen ( 2, 6, 12, dan 13), $12 \mathrm{~mm}$ untuk spesimen (1, 7, 8, 9, dan 14), dan 9.5 mm untuk spesimen (4,5, 10, dan 11), Bhimadi [9].

Tabel 1. Pemilihan Dimensi dan Beban Fatigue

\begin{tabular}{ccccccc}
\hline No.Spes. L.Desain $(\mathrm{mm})$ & L.Riil $(\mathrm{mm})$ & T.Desain $(\mathrm{mm})$ & T. Riil $(\mathrm{mm})$ & D.desain $(\mathrm{mm})$ & D.Riil $(\mathrm{mm})$ \\
\hline 1. & 50 & 50.10 & 3 & 3.05 & 12 & 12.50 \\
2. & 50 & 49.96 & 3 & 3.08 & 15 & 15.06 \\
3, & 50 & 50.04 & 3 & 3.10 & 20.75 & 22.06 \\
4. & 30 & 29.74 & 8 & 8.14 & 9.5 & 9.66 \\
5. & 30 & 29.44 & 8 & 8.04 & 9.5 & 9.62 \\
6. & 60 & 60.34 & 3 & 2.96 & 15 & 15.06 \\
7. & 35 & 35.30 & 6 & 5.74 & 12 & 12.40 \\
8. & 35 & 34.96 & 8 & 8.02 & 12 & 12.94 \\
9. & 35 & 35.08 & 6 & 5.75 & 12 & 12.55 \\
10. & 30 & 28.90 & 6 & 6.04 & 9.5 & 9.56 \\
11. & 35 & 35.02 & 6 & 5.96 & 9.5 & 9.58 \\
12. & 35 & 35.40 & 8 & 7.60 & 15 & 15.68 \\
13. & 35 & 34.34 & 6 & 5.76 & 15 & 15.08 \\
14. & 60 & 59.50 & 3 & 3.08 & 12 & 12.70 \\
\hline
\end{tabular}

Voltase saat penarikan mesin diperoleh tidak ideal, terutama kondisi minimal diharuskan nol. Hal ini ditunjukkan pada harga voltase pada Electric Control Unit (ECU), sesuai tabel-2.

Tabel 2. Penyimpangan Input Indicator Defleksi dan dari ECU (volt)

\begin{tabular}{ccccc}
\hline No. Spesimen & ideal min & ideal maks. & Dari ECU min. & dari ECU maks. \\
\hline 1. & 390 & 1950 & 400 & 2000 \\
2. & 437.63 & 1750 & 360 & 1740 \\
3, & 341.82 & 1710 & 330 & 1700 \\
4. & 441.22 & 2207.62 & 460 & 2200 \\
5. & 398 & 1990 & 400 & 1962 \\
6. & 335 & 1675 & 330 & 1677 \\
7. & 372 & 1864 & 370 & 1870 \\
8. & 488 & 2445 & 490 & 2447 \\
9. & 490 & 2450 & 431 & 2580 \\
10. & 408.89 & 2046.10 & 400 & 2000 \\
11. & 350 & 1749 & 352 & 1755 \\
12. & 460 & 2310 & 448 & 2311 \\
13. & 390.50 & 1962.44 & 398 & 1902 \\
14. & 310 & 1550 & 319 & 1555 \\
\hline
\end{tabular}

Perbedaan junlah siklus pada saat awal retak terjadi dan panjang retak saat specimen patah, di nyatakan dalam tabel-3 dan tabel-4. Sisi-A sampai sisi-D menyatakan ke-4 permukaan specimen.

Tabel 3. Jumlah siklus beban awal retak mikroskop

\begin{tabular}{ccccc}
\hline No. Spesimen & siklus sisi-A & siklus sisi-B & siklus sisi-C & siklus sisi-D \\
\hline 1. & 2980 & 3690 & 5700 & 5850 \\
2. & 480 & 1040 & 710 & 820
\end{tabular}


Seminar Nasional Penelitian dan Pengabdian kepada Masyarakat Universitas Sang Bumi Ruwa Jurai Tahun 2020

\begin{tabular}{ccccc}
3, & 100 & 300 & 150 & 400 \\
4. & 250 & 350 & 3200 & 3000 \\
5. & 3200 & 3400 & 3000 & 7000 \\
6. & 500 & 300 & 400 & 100 \\
7. & 600 & 400 & 5200 & 5500 \\
8. & 15110 & 12300 & 20910 & 18870 \\
9. & 1400 & 21700 & 1450 & 1300 \\
10. & 4300 & 9800 & 1100 & 1200 \\
11. & 1000 & 1400 & 21700 & 300 \\
12. & 300 & 100 & 9940 & 6030 \\
13. & 8750 & 13750 & 400 & 500 \\
14. & 1450 & 1270 & 5980 & 6980 \\
\hline
\end{tabular}

Universitas Sang Bumi Ruwa Jurai Tahun 2020

Tabel 4. Panjang Retak Saat Patah dari Mikroskop

\begin{tabular}{ccccc}
\hline No. Spesimen & sisi-A $(\mathrm{mm})$ & sisi-B $(\mathrm{mm})$ & sisi-C $(\mathrm{mm})$ & sisi-D $(\mathrm{mm})$ \\
\hline 1. & 2.53 & 2.71 & 1.90 & 1.20 \\
2. & 3.83 & 3.55 & 5.89 & 5.94 \\
3, & 0.50 & 0.04 & 4.15 & 6.07 \\
4. & 2.10 & 2.23 & 7.02 & 5.56 \\
5. & 0.08 & 0.12 & 5.62 & 2.24 \\
6. & 15.31 & 11.23 & 9.25 & 11.90 \\
7. & 4.10 & 4.93 & 4.18 & 7.45 \\
8. & 15.86 & 15.77 & 1.10 & 9.43 \\
9. & 4.87 & 26.92 & 26.40 & 11.01 \\
10. & 5.31 & 9.93 & 2.25 & 3.23 \\
11. & 11.35 & 9.30 & 9.20 & 9.75 \\
12. & 6.17 & 4.88 & 3.35 & 1.20 \\
13. & 1.99 & 5.01 & 9.14 & 10.12 \\
14. & 2.38 & 4.64 & 4.70 & 3.05 \\
\hline
\end{tabular}

Rasio beban (R) sebagai perbandingan beban aplikasi terhadap beban ultimate, digunakan yaitu: 0.9 untuk spesimen-1 sampai dengan spesimen-4, 0.7 untuk spesimen-5 dan spesimen-6, 0.9 untuk spesimen-7 dan spesimen-9 serta spesimen-11. Specimen sisanya digunakan rasio beban 0.7. Tebal plat SS-304 masing-masing spesimen dibuat dengan: $3 \mathrm{~mm}$ untuk spesimen (1, 2, 3, 6, 11, dan 14), $6 \mathrm{~mm}$ untuk spesimen (7, 10, 11, dan 13), dan $8 \mathrm{~mm}$ untuk spesimen $(4,5,8$, 9, dan 12). Lebar spesimen divariasikan untuk: $60 \mathrm{~mm}$ pada spesimen (5 dan 14), $50 \mathrm{~mm}$ pada spesimen (1,2, dan 3), $40 \mathrm{~mm}$ pada spesimen-9, $35 \mathrm{~mm}$ pada spesimen $(7,8,11,12,13)$, dan 30 mm pada spesimen ( 4, 6, dan 10). Diameter lubang pada plat untuk 14 spesimen ditentukan yaitu: $20.75 \mathrm{~mm}$ untuk spesimen-3, $15 \mathrm{~mm}$ untuk spesimen ( 2, 6, 12,dan 13), $12 \mathrm{~mm}$ untuk spesimen $(1,7,8,9$, dan 14), dan $9.5 \mathrm{~mm}$ untuk spesimen (4,5, 10, dan 11), Bhimadi [9].

\subsection{Pengolahan data hasil uji fatigue}

Harga panjang retak (a) dalam mili meter untuk setiap jumlah delta siklus beban (dn), diperoleh dari pencatatan saat operasional uji fatik. (a) dan (dn) digunakan untuk mendapatkan harga (da/dn). Harga ini ditempatkan pada koordinat Cartesian sebagai koordinat-y. Koordinat$\mathrm{x}$ ditentukan dari perhitungan harga $(\Delta \mathrm{k})$, mengikuti prosedur dari Rocke and Cartwright [10]. Kondisi permukaan mulus sampai ada retak awal dan secara simultan merambat arah permukaan dan arah kedalaman pada daerah-1 dinyatakan dengan persamaan sebagai berikut: 


$$
\Delta \mathrm{k}=\Delta \sigma \sqrt{\pi c}\left(\sum_{i=1}^{n} \beta_{i}\right)
$$

dmana, $(\Delta \sigma)$ selisih beban maksimum dan minimum, (c) panjang retak arah ketebalan, dan ( $\beta$ ) faktor bentuk. $\left(\beta_{\mathrm{i}}\right)$ dinyatakan sebagai akumulasi perkalian sejumlah factor bentuk yang terlibat. Akumulasi factor- $\left(\beta_{\mathrm{i}}\right)$ untuk persamaan- 8 disebutkan yaitu akibat efek: ketebalan, kedalaman rambatan terhadap tebal plate, panjang retak awal yang muncul terhadap diameter lubang, rasio retak awal terhadap setengah panjang retak maksimum, dan rasio rambatan kedalaman terhadap harga kekuatan yield.

Kondisi retak tembus ketebalan kemudian bagian atas dan bawah merambat bersama sampai daya dukung material sudah tidak memungkinkan pada daerah-2, dinyatakan dengan persamaan yaitu:

$$
\Delta \mathrm{k}=\Delta \sigma \sqrt{\pi(d+2 a)}\left(\sum_{i=1}^{n} \beta_{i}\right)
$$

dmana, (d) diameter lubang. Akumulasi factor- $\left(\beta_{\mathrm{i}}\right)$ untuk persamaan-9 disebutkan yaitu akibat efek: lebar rambatan, rasio ketebalan terhadap panjang retak, rasio rambatan retak terhadap kekuatan yield, satu minus dari dua kali penjumlahan panjang retak maksimum dengan panjang retak terhadap lebar rambatan retak, satu atau dua sisi retakan terjadi, jenis unikaksial atau beban pressuare. Kurva perambatan retak hasil uji fatigue digambarkan sebagai kurva-S, yaitu harga $(\mathrm{da} / \mathrm{dn})$ pada ordinat-y dan absis-x untuk $(\Delta \mathrm{k})$.

Kurva-S dari fungsi $(\mathrm{da} / \mathrm{dN})$ terhadap $(\Delta \mathrm{k})$, dinyatakan sebagai kurva-S. 3(tiga) pembagian kurva-S ini disebutkan yaitu: daerah-1 sebelah kiri, kondisi awal retakan terjadi sampai timbul retak awal panjang tertentu. Daerah-1 diberberlakukan untuk operasional produk risiko tinggi karena produk harus tidak cacat sedikitpun, misalnya: desain tali baja, gear, roda pendarat pesawat terbang, dan rod pada baling baling helicopter. Kriteria desain ini disebut kondisi Save Life Design. Daerah-2 posisi tengah kurva diberlakukan sebagai sebuah kurva linear dalam skala logaritmik. Daerah-2 digunakan untuk desain produk dengan regulasi beban fatik, misalnya: body mobil, pegas-damper, frame engine mount pesawat terbang, dan beam mekanisme control umumnya. Kriteria desain ini disebut kondisi Damage Tolerance Design. Daerah-3 posisi paling kanan, diperuntukkan untuk produk dalam tataran operasional yang dapat dideteksi jadwalkan maintenance. Produk dengan maintenance dapat dijadwalkan, misalnya: rantai, pullybelt, gear box, rem, dan kopling. Kriteria desain ini disebut kondisi Fail save, Bhimadi and Muchajan [11].

\subsection{Linearisasi Persamaan Perambatan Retak}

Empat model persamaan perambatan retak sesuai daerah keberlakuannya, dinyatakan dari Dong [12]. Linearisasi persamaan perambatan retak untuk solusi harga sifat fatigue dan harga koefisien persamaan 4 (empat) pakar untuk SS-304, dinyatakan dari, Bhimadi [13].

\subsubsection{Persamaan Paris}

Bentuk Linear Persamaan Paris, dinyatakan sebagai berikut,

$$
\mathrm{da} / \mathrm{dn}=\mathrm{C}(\Delta \mathrm{k})^{\mathrm{m}}
$$

dimana, $\mathrm{C}$ dan $\mathrm{m}$ konstanta Paris, da/dN Laju Perambatan Retak, dan $\Delta \mathrm{k}$ kmaks. $-\mathrm{kmin}$. Efek 'Stress Ratio', notasi ' $R$ ' pada persamaan Paris, belum dilibatkan. Kondisi perambatan retak daerah-2, dan retak awal pada daerah-1, diabaikan. Harga $\mathrm{C}=5.262 \mathrm{E}-12$, dan $\mathrm{m}=2.891$ SS304, diinformasikan oleh, Shuttle Orbiter Division [2]. Harga $\mathrm{C}=5.60 \mathrm{E}-12$ dan $\mathrm{m}=3.25$, untuk SS-304, diberikan juga oleh Hu [1]. Persamaan ini, diperuntukkan pada daerah-2. Harga dua konstanta Paris dari dua pakar ini, ditunjukkan berbeda tampa keterangan penggunaan khusus. 
linearisasi persamaan ini dinyatakan sebagai berikut, $\ln (\mathrm{da} / \mathrm{dn})=\ln \mathrm{C}+\mathrm{m} \ln (\widehat{\Delta \mathrm{k})}$ diidentikan sebagai $\mathrm{y}=\mathrm{a}+\mathrm{b} \mathrm{x}$, dengan $\mathrm{y}=\ln (\mathrm{da} / \mathrm{dn}), \mathrm{a}=\ln \mathrm{C}, \mathrm{b}=\mathrm{m}$, dan $\mathrm{x}=\ln (\Delta \mathrm{k})$. Regresi linear dengan korelasi, $\mathrm{y}=\mathrm{a}+\mathrm{bx}$ dan $\mathrm{a}=\tilde{\mathrm{y}}-\mathrm{b} \mathrm{x}($ rata-rata), diperoleh,

$$
\mathrm{b}=\frac{n \sum_{i=1}^{n} x_{i} y_{i}-\left(\sum_{i=1}^{n} x_{i}\right)\left(\sum_{i=1}^{n} y_{i}\right)}{n \sum_{i=1}^{n} x_{i}^{2}-\left(\sum_{i=1}^{n} x_{i}\right)^{2}}
$$

\section{Persamaan Walker}

Bentuk Parabolik Persamaan Walker untuk daerah-1 dan 2, dinyatakan sebagai berikut,

$$
\mathrm{da} / \mathrm{dn}=\mathrm{C} \mathrm{kmaks}^{\mathrm{m}}(\Delta \mathrm{k})^{\mathrm{n}}
$$

4(empat) konstanta disebutkan dalam persamaan Walker. Linearisasi persamaan dinyatakan sebagai, $\ln (\mathrm{da} / \mathrm{dn})=\ln \left(\mathrm{C}\left(\mathrm{K}_{\max }\right)^{\mathrm{m}}(\Delta \mathrm{k})^{\mathrm{n}}\right)$. Persamaan ini dijabarkan menjadi, $\ln (\mathrm{da} / \mathrm{dn})$ $=\ln \mathrm{C}+\mathrm{m} \ln \left(\mathrm{K}_{\max }\right)+\mathrm{n} \ln (\Delta \mathrm{k})$. Hasil ini diidentikkan sebagai persamaan $\mathrm{y}=\mathrm{a}+\mathrm{b}$, dengan $\mathrm{y}$ $=\ln (\mathrm{da} / \mathrm{dn}), \mathrm{a}=\ln \mathrm{C}+\mathrm{m} \ln \left(\mathrm{K}_{\max }\right), \mathrm{b}=\mathrm{n}, \mathrm{x}=\ln (\Delta \mathrm{k})$, harga $\mathrm{C}$ dan $\mathrm{m}$ diperoleh dari harga konstanta Paris. $\ln \left(\mathrm{K}_{\max }\right)+(\mathrm{n} / \mathrm{m}) \ln (\Delta \mathrm{k})$ diperoleh sama dengan $\ln (\Delta \mathrm{k})$, dan $\ln \left(\mathrm{K}_{\max }\right)=$ $\ln (\Delta \mathrm{k})-(\mathrm{n} / \mathrm{m}) \ln (\Delta \mathrm{k}) . \mathrm{K}_{\max }$ setiap specimen diperoleh dengan asumsi harga $(\Delta \mathrm{k})$ rata rata. Harga (n) terkecil dipilih. Harga ini didasarkan dari penyebab perubahan harga $K_{\text {max }}$ yang tidak significant.

Universitas Sang Bumi Ruwa Jurai Tahun 2020

\section{Persamaan Forman}

Bentuk Hiperbola Persamaan Forman, dinyatakan sebagai berikut,

$$
\mathrm{da} / \mathrm{dn}=\left(\mathrm{Cf}(\Delta \mathrm{k})^{\mathrm{nf}}\right) /((1-\mathrm{R}) \mathrm{kc}-\Delta \mathrm{ko})
$$

Konstanta R dan kc, dilibatkan oleh Forman pada persamannya. Kedua konstanta ini, diberlakukan pada daerah-2 dan daerah-3. Retakan pada daerah-3 diberlakukan mulai harga $\Delta \mathrm{ko}=(1-\mathrm{R}) \mathrm{kc}$. Linearisasi persamaan Forman dari 3(tiga) konstanta (Cf, nf, dan kc), dinyatakan sebagai berikut, $\ln (\mathrm{da} / \mathrm{dn})=\ln \left\{\mathrm{Cf}(\Delta \mathrm{k})^{\mathrm{nf}} /[(1-\mathrm{R}) \mathrm{kc}-\Delta \mathrm{ko}]\right\}=\ln \mathrm{Cf}(\Delta \mathrm{k})^{\mathrm{nf}}-$ $\ln [(1-\mathrm{R}) \mathrm{kc}-\Delta \mathrm{ko}]=\ln \mathrm{Cf}-\ln [(1-\mathrm{R}) \mathrm{kc}-\Delta \mathrm{ko}]+\mathrm{n} \ln (\Delta \mathrm{k})$. Persamaan linear diasumsikan dengan $\mathrm{y}=\mathrm{a}+\mathrm{bx}$, dimana, $\mathrm{y}=\ln (\mathrm{da} / \mathrm{dx}), \mathrm{a}=\ln \mathrm{Cf}-\ln [(1-\mathrm{R}) \mathrm{kc}-\Delta \mathrm{ko}], \mathrm{b}=\mathrm{nf}$, dan $\mathrm{x}=\ln (\Delta \mathrm{k})$. Harga a dan $b$ sudah diperoleh dari harga untuk perhitungan persamaan Paris. maka harga kc dan $\Delta$ ko diperoleh.

\subsubsection{Persamaan Collipriest (rumus umum)}

Bentuk Kurva-S Persamaan Collipriest untuk daerah-1 sampai daerah-3, dinyatakan sebagai berikut, $\mathrm{da} / \mathrm{dn}=\mathrm{C}(\mathrm{kc} \Delta \mathrm{ko})^{\mathrm{n} / 2} \exp \left[\ln (\mathrm{kc} / \Delta \mathrm{ko})^{\mathrm{n} / 2} \operatorname{arctgh}\left(\ln \left(\Delta \mathrm{k}^{2} /((1-\mathrm{R}) \mathrm{kc} \Delta \mathrm{ko})\right) /(\ln (1-\mathrm{R}) \mathrm{kc} / \Delta \mathrm{ko})\right)\right)$

4(empat) konstanta (C, nc, kc, $\Delta \mathrm{ko})$, dinyatakan oleh Collipriest. Dengan asumsi $\mathrm{y}=\ln (\mathrm{da} / \mathrm{dn})$ dan $\mathrm{x}=\ln (\Delta \mathrm{k})$, linearisasi persamaan ditulis sebagai berikut,

$\ln (\mathrm{da} / \mathrm{dn})=$

$\ln \left\{\mathrm{C}(\mathrm{kc} \Delta \mathrm{k})^{\mathrm{nc} / 2} \exp \left[\ln (\mathrm{kc} / \Delta \mathrm{ko})^{\mathrm{nc} / 2} \operatorname{arc} \tanh \ln \left[\left\{\Delta \mathrm{k}^{2} /\{(1-\mathrm{R}) \mathrm{kc} \Delta \mathrm{ko}\}\right\}-\{(1-\mathrm{R}) \mathrm{kc} / \Delta \mathrm{ko}\}\right]\right]\right\}$

Hal ini diidentikkan dengan persamaan berikut,

$$
y=a+b x+c x^{2}
$$

dimana,

$$
\mathrm{y}=\ln (\mathrm{da} / \mathrm{dn}) \text { dengan, }
$$




$$
\begin{aligned}
& \mathrm{a}=\ln \mathrm{C}+(\mathrm{n} / 2) \ln \mathrm{kc}+(\mathrm{nc} / 2) \ln (\mathrm{e}) \ln \mathrm{kc}-(\mathrm{nc} / 2) \ln (\mathrm{e}) \ln (\Delta \mathrm{ko})+\operatorname{arc} \tanh \ln \\
& \mathrm{b}=\mathrm{nc} / 2 \\
& \mathrm{c}=\operatorname{arctanh} \ln \frac{\ln (e)}{(1-R) k c(\Delta k o)}
\end{aligned}
$$

\section{HASIL DAN PEMBAHASAN}

4(empat) panjang retak, masing masing pada dua pada permukaan sisi kiri dan kanan lubang, dihitung harga rata rata. Delta harga ini terhadap delta siklus beban, digunakan sebagai ordinat kurva perambatan retak dari uji fatigue. Harga $(\Delta \mathrm{k})$ untuk setiap panjang retak ditentukan sesuai: persamaan-1 untuk retakan belum menembus ketebalan dan persamaan-2 untuk retakan merambat sepanjang ketebalan plat. Kurva ditampilkan dalam skala log-log. Hasilnya untuk specimen-11, dinyatakan dalam gambar-1. Tujuh penyimpangan saat operasional uji fatik terjadi hasil pengamatan, misalnya adalah (Bhimadi. 2004): pengukuran dimensi spesimen (ukuran $3 \mathrm{~mm}$ hasilnya menyimpang $0.04 \mathrm{~mm}$ sampai $0.5 \mathrm{~mm}$ ), penyimpangan harga indikator ECU (diinginkan $275 \mathrm{~N}$ sampai $2445 \mathrm{~N}$ memberi penyimpangan $1.01 \mathrm{~N}$ sampai $47 \mathrm{~N}$ ), dan pemilihan selang waktu pengamatan menimbulkan perbedaan harga siklus beban pada permukaan A-B-C-D (spesimen-6 dengan N masing masing 3200, 3200, 3000, 5500).

Koordinat mendatar dalam kurva, digunakan untuk spesimen kondisi rambatan retak dari struktur mulus sampai timbul initial crack sesuai regulasi. Regulasi diberikan untuk SS-304 dengan retak awal 0.0125 inc. Sifat fatigue SS-304 diperoleh dengan prosedur ini. $\mathrm{K}_{\text {maks }}$ atau Maximum Stress Intensity Factor (Faktor Intensitas Tegangan Maksimum) material patah, dihitung dari akumulasi setiap data $(\Delta \mathrm{k})$ pada absis. Contoh sifat fatigue untuk specimen-11 ditampilkan pada gambar-1. Harga $K_{\text {maks }}$ sesuai tabel-1 untuk specimen-11, diperoleh 1240.136 $\mathrm{MPa} \mathrm{m}^{\wedge} 0.5$. Harga sifat fatigue lain dari specimen-11 diperoleh yaitu: (kc) atau Plane Stress Universitas Sang Bumi Ruwa Jurai Tahun 2020

Fracture Toughness $28.843 \mathrm{MPa} \mathrm{m}^{\wedge} 0.5$, dan harga $(\Delta \mathrm{ko})$ atau Delta Faktor Konsentrasi Tegangan pada kondisi struktur mulus dari persamaan-6 yaitu $2.8843 \mathrm{MPa}^{\wedge} 0.5$, (Kic) atau Plane Strain Fracture Toughness sama dengan $6.9859 \mathrm{MPa} \mathrm{m}^{\wedge} 0.5$, dan $\left(\mathrm{k}_{\mathrm{th}}\right)$ atau Intensitas Tegangan Threshold dari regresi kondisi retak mulai merambat dalam daerah-1 yaitu 0.31317 $\mathrm{MPa} \mathrm{m}^{\wedge} 0.5$.

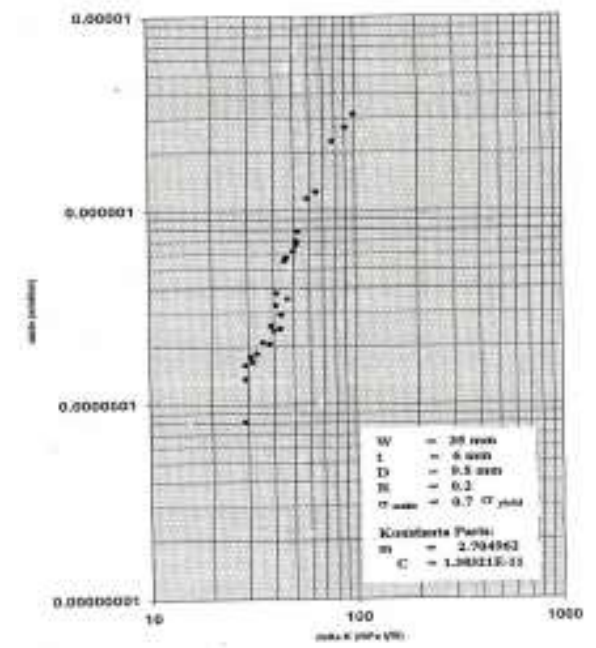

Gambar 1. Kurva (da/dn) fungsi $(\Delta \mathrm{k})$ untuk specimen-11

Tabe1 5 Harga Sifat Fatigur 14 Spesimen 
Seminar Nasional Penelitian dan Pengabdian kepada Masyarakat Universitas Sang Bumi Ruwa Jurai Tahun 2020

\begin{tabular}{cccccccc}
\hline No. Spesimen & Kth & \multicolumn{1}{c}{ Kic } & \multicolumn{2}{c}{ Kc } & \multicolumn{2}{c}{ Kmaks } & \multicolumn{2}{c}{ Ko Korman } & \multicolumn{2}{c}{ Kmaks Walker } \\
\hline 1. & 0.289418537 & 7.198121212 & 38.381 & 437.405 & 3.8381 & 48.3 & 454.1505626 \\
2. & 0.30201553 & 18.840175 & 35.342 & 376.919 & 3.5342 & 45.34 & 385.7095805 \\
3, & 0.314668417 & 31.90221311 & 22.559 & 154.702 & 2.2559 & 32.5 & 163.5173028 \\
4. & 0.30454201 & 11.28407423 & 20.823 & 706.326 & 2.0823 & 30.8 & 767.0999794 \\
5. & 0.270572001 & 7.239285714 & 18.381 & 115.873 & 5.5143 & 21.7 & 121.9606177 \\
6. & 0.312265653 & 11.38387774 & 16.525 & 761.996 & 4.9575 & 20.001 & 843.3837372 \\
7. & 0.306840939 & 11.15555636 & 23.231 & 1235.247 & 2.3231 & 33.2 & 1285.172249 \\
8. & 0.279320035 & 15.532025 & 17.046 & 873.94 & 5.1138 & 20.3 & 950.6629544 \\
9. & 0.273369601 & 12.8001634 & 18.082 & 856.885 & 1.8082 & 28.001 & 889.5598531 \\
10. & 0.287571677 & 9.945914179 & 26.347 & 392.18 & 7.9041 & 29.68 & 407.3899684 \\
11. & 0.313167789 & 6.985910714 & 28.843 & 1240.136 & 2.8843 & 38.845 & 1278.67424 \\
12. & 0.295531509 & 8.051492359 & 23.515 & 717.26 & 7.0545 & 26.85 & 743.7773762 \\
13. & 0.311556726 & 26.84008333 & 52.579 & 2411.514 & 15.7737 & 55.88 & 2466.495044 \\
14. & 0.289978562 & 6.510439865 & 20.662 & 535.673 & 6.1986 & 24 & 557.2104645 \\
\hline
\end{tabular}

Universitas Sang Bumi Ruwa Jurai Tahun 2020

Spesimen dengan tebal $6 \mathrm{~mm}$ maupun dengan tebal $8 \mathrm{~mm}$, open hole $8.5 \mathrm{~mm}$, semula dengan rasio beban 0.7 kemudian naik menjadi 0.9, diperoleh semua sifat fatigue SS-304 (Kth, Kic, Kc, Kmax naik, kecuali $\Delta$ ko turun. Rasio beban (0.7 atau 0.9)dan lubang (9.5 mm, atau 12 $\mathrm{mm}$, atau $15 \mathrm{~mm}$ ) tetap, tebal spesimen naik dari $3 \mathrm{~mm}$ nebjadi $8 \mathrm{~mm}$, maka $\mathrm{Kth}, \mathrm{Kc}$ dan $\Delta$ ko turun. Kic dan Kmax naik. Tebal spesimen $8 \mathrm{~mm}$ dengan diameter lubang $12 \mathrm{~mm}$ atau Universitas Sang Bumi Ruwa Jurai Tahun 2020 dengan diameter lubang $15 \mathrm{~mm}$ dibuat tetap, dengan rasio beban naik menyebabkan semua sifat fatik SS-304 turun. Kc dari persamaan Forman, lebih besar dari hasil uji fatik. Hal ini akibat pemilihan keterlibatan faktor bentuk perlu ditinjau syarat cukup yaitu: semakin banyak faktor bentuk dilibatkan, semakin kecil Kmax dari uji fatigue. Kmax dari persamaan Walker lebih besar dari hasil uji fatigue. Hal ini karena fenomena mau patah riil terjadi cepat, sehingga lambat terdeteksi. Evaluasi pilihan factor bentuk yang dilibatkan akan optimal apabila perbedaan Kmax antara hasil uji dengan perhitungan kembali oleh persamaan walker, signifikan cukup kecil.

Data dari uji fatik 14 spesimen plat Stainless Steel 304 (SS-304) beban fatik amplituda konstan, dievaluasi dengan variasi: tebal, diameter lubang, dan rasio beban. Hasil observasi uji fatik SS-304 diperoleh, tebal $3 \mathrm{~mm}$ konstan dan rasio beban 0.9 konstan dan pertambahan diameter lubang dari $12 \mathrm{~mm}$ sampai $20.75 \mathrm{~mm}$, Intensitas Tegangan Threshold $\left(\mathrm{K}_{\mathrm{th}}\right)$ terus naik, Plane Strain Fracture Toughness (Kic) naik terus, Plane Strees Fracture Toughness (Kc) turun terus, $K_{\text {maks }}$ atau Maximum Stress Intensity Factor terus turun, koefisien $C$ persamaan Paris naik tetapi untuk m turun, dan koefisien persamaan Walker naik kemudian turun, tiga koefisien persamaan Collipriest selalu turun kemudian naik atau sebaliknya.

Tabe1 6 Harga Konstanta Persamaan Perambatan Retak dari Pakar

\begin{tabular}{|c|c|c|c|c|c|c|c|}
\hline No. Spes. & 5. C-Paris & m-Paris & n-Walker & (a) & (b) & (c) cf-Forman & \\
\hline 1. & $1.450 \mathrm{E}-13$ & 3.592556 & 1.72619035 & 619.622 & 2.362561875 & 47.15034191 & $1.45072 \mathrm{E}-13$ \\
\hline 2. & 3.560E-13 & 3.476553 & 1.11509545 & 37.0311 & 1.095618356 & 3.924401645 & $3.56015 \mathrm{E}-13$ \\
\hline 3 , & $6.183 E-11$ & 2.500992 & 1.13486536 & 49.5187 & 2.137879779 & 7.422599339 & $6.14735 \mathrm{E}-11$ \\
\hline 4. & $1.251 \mathrm{E}-12$ & 3.649546 & 2.75309204 & 63.3980 & 0.309838008 & 8.713396875 & $1.24831 \mathrm{E}-12$ \\
\hline 5. & $9.488 \mathrm{E}-11$ & 2.449666 & 0.95350479 & 94.6046 & 0.004273447 & 13.0301215 & $9.44725 \mathrm{E}-11$ \\
\hline 6. & $1.099 \mathrm{E}-11$ & 2.171478 & 1.569181 & 31.8282 & 0.387154784 & 5.625422639 & $1.14607 \mathrm{E}-11$ \\
\hline 7. & $2.4383 \mathrm{E}-13$ & 3.929484 & 2.9356833 & 57.0897 & 2.078610669 & 6.806376439 & $2.43067 \mathrm{E}-13$ \\
\hline 8. & $1.048 \mathrm{E}-11$ & 3.293969 & 2.40744173 & 20.9984 & 0.710291479 & 4.34943872 & $1.0237 \mathrm{E}-11$ \\
\hline
\end{tabular}


Seminar Nasional Penelitian dan Pengabdian kepada Masyarakat

Universitas Sang Bumi Ruwa Jurai Tahun 2020

\begin{tabular}{cccccccc}
9. & $2.160 \mathrm{E}-11$ & 2.900434 & 1.60827065 & 36.5999 & 0.707884416 & 6.016546308 & $2.14277 \mathrm{E}-11$ \\
10. & $4.930 \mathrm{E}-12$ & 3.105209 & 1.7045106 & 178.758 & 3.029279682 & 17.2699067 & $4.92992 \mathrm{E}-12$ \\
11. & $6.869 \mathrm{E}-12$ & 2.897412 & 1.59390732 & 123.803 & 2.023731979 & 11.79674127 & $6.87082 \mathrm{E}-12$ \\
12. & $1.628 \mathrm{E}-09$ & 1.779242 & 1.04609712 & 33.2529 & 0.402396707 & 4.653940037 & $1.62962 \mathrm{E}-09$ \\
13. & $2.252 \mathrm{E}-12$ & 2.800727 & 2.04510271 & 10.5370 & 3.306675601 & 2.486902521 & $2.23018 \mathrm{E}-12$ \\
14. & $2.390 \mathrm{E}-10$ & 2.101165 & 1.20929135 & 26.5718 & 1.045019877 & 4.331653189 & $2.39412 \mathrm{E}-10$ \\
\hline
\end{tabular}

Dari uraian dimensi dan perlakukan beban fatik untuk 14 spesimen dan dengan mengikuti hasil perhitungan koefisien sifat material fatik sesuai tabel-5 dan tabel-6, makin lebar diameter lubang dari hasil uji spesimen-1 diameter $12 \mathrm{~mm}$ sampai spesimen-3 diameter $20.75 \mathrm{~mm}$, diperoleh harga $(\mathrm{C}, \mathrm{n}$, dan $\Delta \mathrm{ko})$ naik kemudian turun, kecuali harga $\mathrm{kc}$ terus turun. Pada spesimen-6 diameter $8 \mathrm{~mm}$ dan spesimen-10 diameter $6 \mathrm{~mm}$, makin tebal plat diperoleh penurunan harga untuk semua parameter sifat material. Perbedaan spesimen-5 lebar 60mm dan spesimen-12 lebar $35 \mathrm{~mm}$ untuk parameter spesimen yang lain sama, menunjukkan harga $\mathrm{C}$ dan $\mathrm{n}$ turun, dan yang lainnya naik. Prosentase tegangan maksimum naik dari 0.7 untuk spesimen- 6 dengan 0.9 untuk spesimen-4, memperoleh harga $\mathrm{n}$ turun dan harga yang lain naik.

Dari pengamatan, dapat dianalisa dalam hal, kecenderungan perubahan dimensi dan beban terhadap perubahan harga parameter material. Hasilnya adalah: pola perubahan 4(empat) harga parameter material yang naik kemudian turun merupakan penunjukan untuk mendapat satu harga maksimum masing-masing yang digunakan sebagai harga referensi yang berlaku untuk kondisi yang sudah disebutkan dan diameter tertentu dimana harga parameter maksimum.

\section{KESIMPULAN}

Kecenderungan sifat fatik apakah naik atau turun, ditunjukkan dalam pola dari perubahann harga dimensi spesimen dan rasio beban. Pola kecenderungan ini diperoleh, setelah dilakukan linearisasi persamaan perambatan retak dari pakar dalam skala lon, Makin lebar diameter lubang dari hasil uji spesimen-1 dengan diameter $12 \mathrm{~mm}$ sampai spesimen-3 dengan diameter $20.75 \mathrm{~mm}$, diperoleh harga $(\mathrm{C}, \mathrm{n}$, dan $\Delta \mathrm{ko}$ ) naik kemudian turun, kecuali harga kc terus turun. Spesimen-6 diameter $8 \mathrm{~mm}$ dan spesimen-10 diameter $6 \mathrm{~mm}$, makin tebal plat diperoleh penurunan harga untuk semua parameter sifat material.

Semua parameter material untuk kenaikan satu aspek dimensi atau satu aspek beban yang berurut untuk aspek lain harga sama dan dengan jumlah spesimen yang cukup, memberikan kondisi harga optimal pada harga dari aspek tertentu tersebut. Sehingga referensi harga C dan n material dari literatur harus dinyatakan berlaku pada kondisi uji fatik tertentu.

Penelitian ini merupakan awal untuk menentukan kecenderungan perubahan harga sifat fatik SS-304, sehingga penelitian lanjut dengan repetisi dan jumlah material cukup sesuai kebutuhan variasi ukuran, perlu didefinisikan kembali untuk mendapatkan harga pamareter fatik akurat. Evaluasi hasil uji fatik perlu dikembangkan tidak hanya menggunakan linearisasi tetapi juga teori dan metoda atau teori lain yang sesuai untuk keanekaragaman misalnya dalan hal: dimensi, beban, error, kondisi mesin, dan human error.

\section{UCAPAN TERIMAKASIH}

Kami sampaikan terima kasih kepada yang tidak dapat kami sebutkan satu per satu atas bantuan dan kesempatan diskusi, dimana penelitian ini didukung dengan pelaksanaan uji fatik dari Lab. Konstruksi Kapal, Teknik Bangunan Kapal - ITS, dan bantuan dana serta bahasan dan diskusinya di Lab. Desain Jurusan Mesin, Institut Teknologi Adhi Tama Surabaya (ITATS), sampai penelitrian dapat dituangkan menjadi nakalah ini. 


\section{DAFTAR PUSTAKA}

Bhimadi, T., (2014), Konsep Teknologi, Penerbit Umiversitas Negeri Surabaya Press, halaman4, terbitan-1, cetakan-1, ISBN: 978-979-643-6, Surabaya, Indonesia.

Bhimadi, T., (2011), Dasar Dasar Getaram Mekanis, Penerbit ANDI, halaman-14, terbitan-1, cetakan-1, ISBN: 978=979-29-1683-8, Yogyakarta, Indonesia

Bhimadi, T., (1998), Perambatan Retak Plat Open Hole Stainless Steel 304 Akibat Beban Uniaksial Amplituda Konstan, Thesis, Program Studi Teknik Mesin, Institut Teknologi Sepuluh Nopember, Surabaya, Indonesia.

Juvinal, R. C., (1967), Sterss, Strain, and Strength, McGraw-Hill Book Company, Series in Mechanical Engineering, Michigan, USA.

Hu, T, (1979), Advanced Crack Propagation Predictive Analysis Computer Program - IBM System, Journal of Cosmic NASA, Universitas Georgia, USA.

Shuttle Orbiter Division, (1979), Fracture Mechanics Properties of Materials Used in Space Shuttle Orbiter Structure, Journal of Rockwell International, SOD 79-0219, USA.

Schijve, J., (1979), Four Lecture on Fatigue Crack Growth, Kuliah Tamu, Kelompok Bidang Keahlian Teknik Penerbangan, Jurusan Teknik Mesin, ITB, Bandung, Indonesia.

Dieter, G. E. JR., (1961), Machanical Metallurgy, McGraw-Hill Book Company, Yoronto, Canada.

Bhimadi, T,. (2004), Penyimpangan Uji Fatigue 14 Spesimen Plat Berlubang Lebar $50 \mathrm{~mm}$ dan Tebal sampai $8 \mathrm{~mm}$ SS-304 Beban Uniaksial, Seminar Nasional Universitas Muhammadiyah Surakarta, Sabtu 11 Desember 2004, Dengan Tema: Perancangan dan Aplikasi Teknologi dalam Pembangunan (RAPI-2004), Tercatat dalam ISSN : 1412 9612 , Surakarta, Indonesia.

Rocke, D., P., and Cartwright, D. J., (1976), Compendium of Stress Intensity Factor, Her Majesty's Stasionary Office, London, UKGB.

Bhimadi, T., dan Muchajan, M., (1991), Tinjauan Aspek Perancangan dalam Pembuatan Struktur N250, Jurnal Seminar Nasional, Experimental mechanics-91, ITB, Bandung.

Dong, Z., J. (1998), Modelisation Numerique de L'interaction Mecanique Entre Fissures Paralleles et Application en Fatigue, These Ecole Nationale Superiuere des Sciences Fondamentals et Appliquees, Poitiers, France.

Bhimadi, T., (2003), Perambatan Retak Amplituda Konstan Lubang Plat SS-304, Jurnal Seminar Nasional, Peran Riset dan Teknologi Bidang Teknik Mesin, dipresentasikan 11 Oktober di Universitas Brawijaya, ISBN : 979-9723-1-9, Malang 